\title{
Are epizoites biological indicators of a western Mediterranean striped dolphin die-off?
}

\author{
F. J. Aznar, J. A. Balbuena, J. A. Raga \\ Departamento de Biología Animal, Universidad de Valencia, Dr. Moliner 50, E-46100 Burjasot, Valencia, Spain
}

\begin{abstract}
During a die-off of Mediterranean striped dolphins Stenella coeruleoalba in 1990-91, 82 individuals stranded on the Spanish coast were examined for crustacean ectoparasites and epizoites. Six species were detected: Syncyamus aequus, Pennella sp., Xenobalanus globicipitis, Conchoderma virgatum, Lepas pectinata and Lepas cf. hillii. The barnacles L. pectinata and L. cf. hillii are reported here for the first time on cetaceans; they were attached to the teeth. $C$. virgatum was also found on the teeth; this is an unusual attachment on cetaceans. $X$. globicipitis showed a higher prevalence on the dolphins studied than on those stranded in the same months before (1980 to 1990) and after (1991 to $1993)$ the epizootic. An analysis of shell and pseudocapitulum sizes of the $X$ globicipitis infrapopulations indicated possible recent colonization. It is suggested that settlement of some epizoites might have increased due to reduced movement of the dolphins and/or impaired regenerative and immune functioning of the skin prior to death. This might account for the exceptional occurrence of Lepas spp. attached on the teeth, the unusual attachment of $C$. virgatum, and the higher prevalence and apparently young infrapopulations of $X$. globicipitis
\end{abstract}

KEY WORDS: Epizoites · Crustaceans · Cetacea $\cdot$ Striped dolphin - Die-off - Mediterranean

\section{INTRODUCTION}

A number of symbiotic crustacean species can be found on cetaceans, establishing associations ranging from commensalism to parasitism (Arvy 1982). The degree to which barnacles (Cirripedia) have adapted to living on cetaceans varies. Some species, such as stalked barnacles of the genera Conchoderma and Lepas (Lepadidae), can be considered generalists because they occur on both living organisms (turtles, cetaceans, etc.) and inanimate objects (hulls of ships, floating items). In contrast, other species [sessile or acorn barnacles of the genera Coronula, Cryptolepas, Tubicinella and Xenobalanus (Coronulidae)] are more specialized and are found only on cetaceans (Clarke 1966, Raga in press).

Two main factors related to the cetacean host seem to influence colonization of the skin by symbiotic crustaceans. One is the mobility and hydrodynamism of the host. In the case of the grey whale Eschrichtius robustus, it has been shown that barnacles are arranged on the whale's body surface according to the currents generated by swimming movements (Kasuya \& Rice 1970). In addition, the abundance of certain ectoparasitic amphipods (whale-lice, Cyamidae) appears to be inversely proportional to the swimming speed of the cetacean species (Berzin \& Vlasova 1982). The second factor affecting colonization is molting, at least in the case of sessile crustacean species. It has been suggested that molting by the whale may be a mechanism which causes or perhaps facilitates the detachment of barnacles from the host (Scarff 1986).

The striped dolphin Stenella coeruleoalba is the most common cetacean in the western Mediterranean Sea (Duguy 1989, Aguilar 1991). From July 1990 to early 1991, a viral epizootic infection affected this species in the Spanish Mediterranean (Domingo et al. 1990, Van Bressem et al. 1991). During this period, a considerable increase in strandings of striped dolphins was noted. Many dolphins were still alive when found on the beach but all died after several hours (Aguilar \& Raga 1993). Necropsies revealed severe encephalitis and/or pneumonia, which probably was the cause of death (Domingo et al. 1992, Duignan et al. 1992). It is esti- 
mated that several thousand dolphins died throughout the Mediterranean Sea due to this epizootic (Aguilar \& Raga 1990, Bompar et al. 1991, Webb 1991, Bortolotto et al. 1992, Cebrian 1992).

The aim of this paper is to describe the ectoparasitic and epizoitic fauna on striped dolphins affected by the viral epizootic, providing the most comprehensive study of this host species to date. In addition, we investigate the possible effects of the epizootic on some of these crustacean species, because the mobility and physiology of their hosts seemed seriously affected. Among the species of crustaceans detected, we chose Xenobalanus globicipitis for studying possible population changes during the die-off. This choice was made because it was the most abundant and persistent species. The body of some of these epizoites may be damaged due to erosion during strandings or to subsequent transportation and handling of the dolphins. However, the calcareous basal shell of $X$. globicipitis remains firmly attached to the host. These shells are not only a good indicator of the presence of these barnacles but of their relative age (see below).

\section{MATERIALS AND METHODS}

Eighty-two striped dolphins stranded between July 1990 and January 1991 on the Spanish Mediterranean coast were thoroughly examined for ectoparasites and epizoites, but only 68 and 64 individuals were surveyed for the amphipod Syncyamus aequus and the barnacle Xenobalanus globicipitis, respectively. All dolphins showed different pathological lesions that could be attributed to the above-mentioned virus (Duignan et al. 1992).

The crustacean specimens were fixed and preserved in $70 \%$ ethanol. This material is deposited at the collection of the Department of Animal Biology, University of Valencia.
We compared the prevalence of Xenobalanus globicipitis on Mediterranean striped dolphins during the epizootic by examining 15 and 6 individuals found respectively before (1980 to 1990) and after (1991 to October 1993) the outbreak. We only chose dolphins stranded during the same months as those affected by the epizootic, in order to eliminate the possible effect of seasonal variations. Only prevalence analysis was possible because other relevant data were not available from dolphins stranded before the epizootic and the 6 obtained after 1991 harboured no X. globicipitis.

We also analyzed the growth of Xenobalanus globicipitis individuals on each dolphin stranded during the epizootic (i.e. the infrapopulations). This study was restricted to dolphins from September 1990 (21 individuals) to remove the potential effect of seasonal changes in growth of the barnacles. $X$. globicipitis body size was estimated for whole specimens as the width of the pseudocapitulum (analogous to the rostrocarinal diameter of normal barnacles). This dimension of the pseudocapitulum is apparentiy the most conservative with respect to age (W. A. Newman pers. comm.). For damaged or missing specimens, we used the maximum diameter of the shell. All measurements were taken to the nearest $0.01 \mathrm{~mm}$ using a gauge.

Statistical analyses were carried out with the SPSS/PC+ statistical package. Ecological terms are used as defined by Margolis et al. (1982).

\section{RESULTS AND DISCUSSION}

Six crustacean species were detected. Their prevalence, intensity of infection and location are presented in Table 1. Four of these species (Syncyamus aequus, Pennella sp., Xenobalanus globicipitis and Conchoderma virgatum) occur commonly on striped dolphins (Dollfus 1968, Pilleri 1970, Raga \& Carbonell 1985, Raga 1988). However, the other 2 species (Lepas pecti-

Table 1. Prevalence, intensity and site of infection for ectoparasites and epizoites detected on Mediterranean striped dolphin Stenella coeruleoalba affected by a viral epizootic in 1990-1991. n: total number of host individuals examined for each species

\begin{tabular}{|c|c|c|c|c|}
\hline Species & $\begin{array}{l}\text { Prevalence of } \\
\text { infection }(\%)\end{array}$ & $\mathrm{n}$ & $\begin{array}{c}\text { Intensity of infection } \\
\qquad(\bar{x} \pm 1 \text { SD })\end{array}$ & Site \\
\hline \multicolumn{5}{|l|}{ Amphipoda } \\
\hline Syncyamus aequus & 19.1 & 68 & $2.9 \pm 1.9$ & Blowhole \\
\hline \multicolumn{5}{|l|}{ Copepoda } \\
\hline Pennella sp. & 30.5 & 82 & $4.6 \pm 6$ & Flanks \\
\hline \multicolumn{5}{|l|}{ Cirripedia } \\
\hline Xenobalanus globicipitis & 51.5 & 64 & $11.7 \pm 14$ & Fins \\
\hline Conchoderma virgatum & 2.4 & 82 & $1.5 \pm 0.7$ & Tooth surface, on Pennella sp. \\
\hline Lepas pectinata & 1.2 & 82 & 4 & Between teeth \\
\hline Lepas cf. hillii & 1.2 & 82 & 2 & Between teeth \\
\hline
\end{tabular}




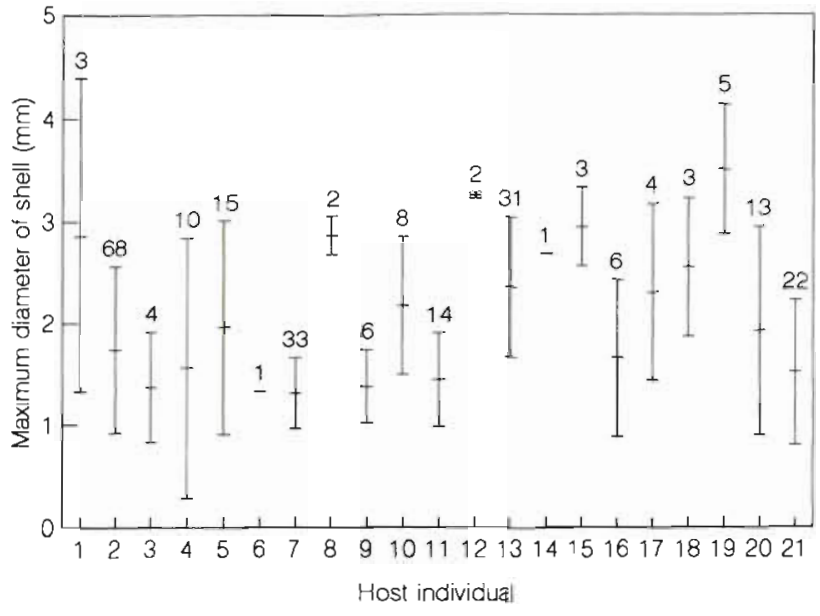

Fig. 1. Xenobalanus globicipitis. Mean shell maxumum dıameters $( \pm \mathrm{SD}$ ) for 21 infrapopulations of barnacles on Stenella coeruleoalba. Numbers above bars indicate population size

nata and L. cf, hillii) had never been reported on cetaceans. Species of the genus Lepas usually occur on floating objects, although some have occasionally been reported on pinnipeds (Bonner 1968, Stirling 1971 . Baldridge 1977). On one occasion, both Lepas species and $C$. virgatum appeared directly affixed to the teeth of a single dolphin. This is an unusual site of attachment on cetaceans, occurring only if the lip or jaw is damaged or deformed exposing the teeth to the outside (Clarke 1966, Perrin 1969). However, the dolphin in question showed no abnormalities in the jaws; it may be that this individual could swim with its mouth open for a certain period of time.

In a mass dolphin mortality on the mid-Atlantic coast of the United States during 1987, an overabundance of 'soft-shelled barnacles' occurred on bottlenose dolphins Tursiops truncatus, suggesting slow movement of possibly sick animals (Brody 1989). This possibility has also been suggested by Aguilar \& Raga (1993) concerning the Mediterranean striped dolphins.

The prevalence of Xenobalanus globicipitis on the striped dolphins stranded before and after the eplzootic was $26.0 \%(n=21)$, versus $51.5 \%$ on those affected by the epizootic $(n=64)$. This seems to favour the hypothesis of easier colonization of this barnacle due to slow movement of the dolphins affected by the epizootic before death. However, the differences in prevalence could not be statistically tested because we could not assume that the 2 samples were actually independent. The dolphins of the first group represented individuals whose death was due to various causes (diseases, injuries, etc.).

Significant differences in the prevalence of Xenobalanus globicipitis with respect to size of dolphins $\left(<180 \mathrm{~cm}\right.$ vs $>180 \mathrm{~cm}$ length; $\chi^{2}=0.72, \mathrm{df}=1, \mathrm{p}>$

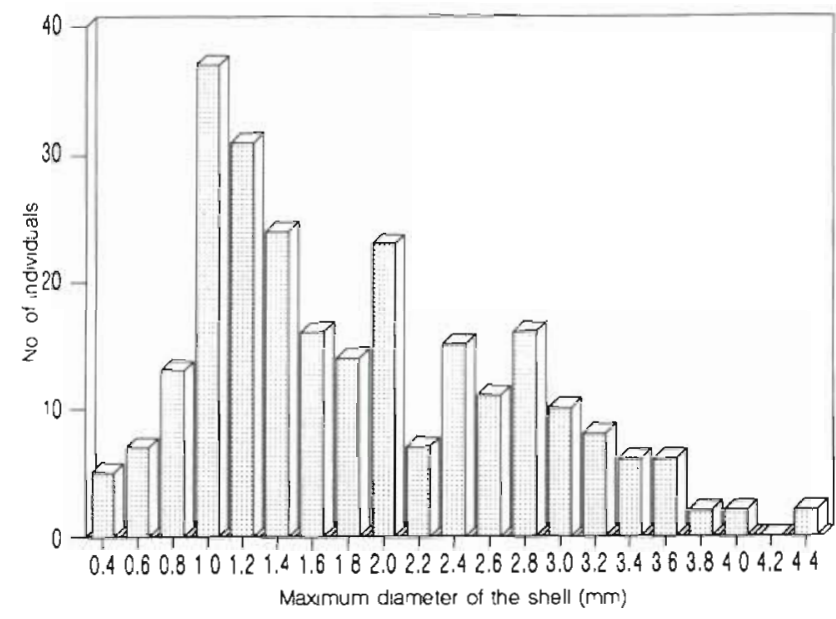

Fig. 2 Xenobalanus globicipitıs Frequency distribution of maxımum shell diameters of barnacles studied from 21 unfrapopulations

0.05 ), or in intensity with respect to size (Spearman rank correlation: $\mathrm{r}=-0.25, \mathrm{n}=41, \mathrm{p}=0.1$ \}, were not $\mathrm{ab}$ served in the sick dolphın sample. Thus, it is assumed that dolphin size had little influence on the prevalence and rate of colonization by this eprzoite.

In Fig. 1 the mean maximum shell diameter of each Xenobalanus globicipitis infrapopulation is given. In Figs. 2 \& 3 the pooled frequency distrubution of shell and pseudocapitulum sizes are shown. The use of shell diameter as a size measure of this species is justified because of the high correlation of this measurement with the pseudocapitulum width in the whole specimens that were analyzed (Pearson correlation of log-transformed data. $r=0.96, n=54, p<0.000$ ) $\left(F_{1 g}\right.$. 4). It is unlikely that age estimates based on pseudocapitulum or shell measurements were blased

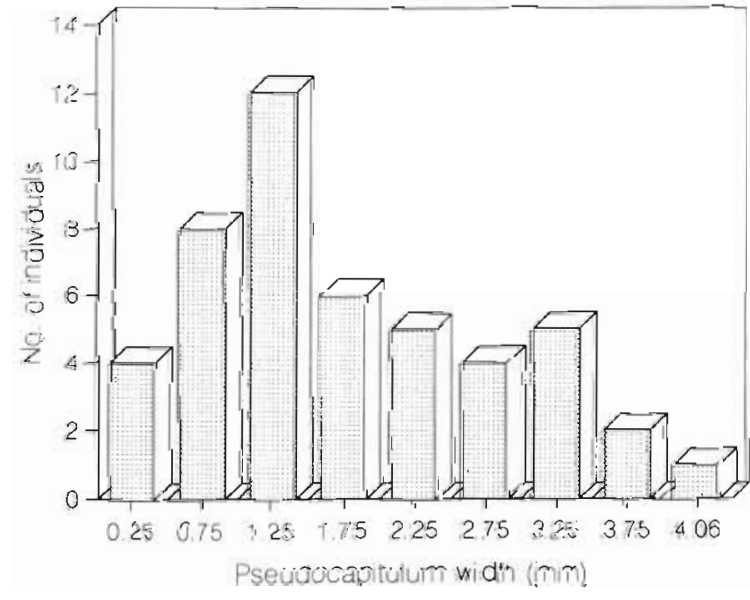

Fig. 3. Xenobalanus globicipitis Frequency distribution of pseudocapitulum widths of barnacles from 21 infrapopulations 


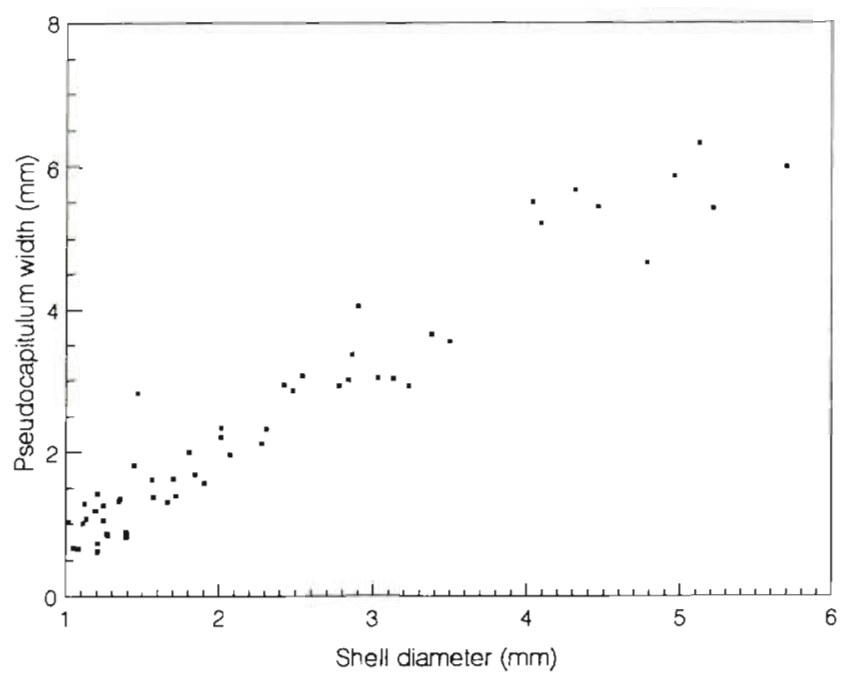

Fig. 4. Xenobalanus globicipitis. Plot of maximum shell diameters vs pseudocapitulum widths

in the case of the largest individuals, because the sizes of the analyzed sample were far from values that would indicate that the animals had stopped growing (see Fig. 2).

Overall, the above results suggest that the Xenobalanus globicipitis infrapopulations were composed mostly of young individuals, the range of sizes being lower than those normally attained by the barnacle on this and other hosts: e.g. shell $7 \mathrm{~mm}$, pseudocapitulum $6.14 \mathrm{~mm}$ on striped dolphins in the Spanish Mediterranean; shell $7.01 \mathrm{~mm}$, pseudocapitulum $9.75 \mathrm{~mm}$ on long-finned pilot whales Globicephala melas in the western Mediterranean; and shell $6.5 \mathrm{~mm}$, pseudocapitulum $6.8 \mathrm{~mm}$ on fin whales Balaenoptera physalus from Iberian Atlantic waters (author's unpubl. data). If we assume that the decreased mobility of the dolphins affected by the epizootic infection occurred shortly before death, most specimens of $X$. globicipitis would have colonized their host during this period, accounting for the young infrapopulations dominated by small individuals. An additional factor might facilitate the attachment of barnacles in diseased animals. In addition, the regenerative and immune functions of the skin seem to be much reduced in sick or debilitated dolphins (J. R. Geraci \& S. H. Ridgway pers. comm.).

It is crucial for this hypothesis that some time elapses between the first appearance of disease symptoms and the death of the dolphins. This time interval would allow the barnacles to affix themselves and grow to a certain stage. Domingo et al. (1992) showed that lung and brain lesions in the dolphins were of a subacute or chronic nature, consistent with a prolonged clinical course and loss of body condition. According to $M$.
Domingo, J. R. Geraci \& S. Kennedy (pers. comm.), the time interval between infection and death is about $40 \mathrm{~d}$, or even longer (A. D. V. E. Osterhaus pers. comm.). In Mediterranean waters, Xenobalanus globicipitis may take 2 to 3 mo to reach the adult stage (Heldt 1950, cited in Arvy 1982).

However, we cannot rule out the possibility that seasonal factors account, to a greater or lesser degree, for the observed population patterns of Xenobalanus globicipitis because the population biology and growth rates of this species are virtually unknown.

Although there is no conclusive evidence supporting an unusual change in epizoic crustaceans on our dolphins, our data suggest that variations in the occurrence, attachment, and population growth of some of the species did occur. Thus, examination of epizoa may prove useful in further studies on diseased cetaceans.

Acknowledgments. We thank Dr W. A. Newman (Scripps Institution of Oceanography, La Jolla, CA) for confirming identification of the barnacles and for providing additional literature and useful criticism on the manuscript. We are also indebted to Dr A. Aguilar and Ms N. Caizada (University of Barcelona) who kindly supplied data about the age of the dolphins. We are grateful to Drs $M$. Domingo (Barcelona Autonomous University), J. R. Geraci (Guelph University) S. Kennedy (Veterinary Science Laboratories, Belfast), A. D. V. E. Osterhaus (National Institute of Public Health and Environmental Protection, Bilthoven) and S. H. Ridgway (Naval Ocean Systems Center, San Diego) for giving valuable information on pathology and epidemiology related to the viral epizootic and regenerative ability of the skin of cetaceans. Finally, we thank M. Fernández, J. Badillo, and J. Salinas for their assistance with the field work. This study was supported by the Interministerial Commission of Science and Technology (CICYT) of the Spanish Government (projects NAT90-1254E and NAT91-1128-C4-1)

\section{LITERATURE CITED}

Aguilar, A. (1991). Calving and early mortality in the western Mediterranean striped dolphin. Stenella coeruleoalba. Can. J. Zool. 69(5): 1408-1412

Aguilar, A., Raga, J. A. (1990). Mortandad de delfines en el Mediterráneo. Polít. Cient. 25: 51-54

Aguilar, A., Raga, J. A. (1993). The striped dolphin epizootic in the Mediterranean Sea. Ambio 22(8): 524-528

Arvy, L. (1982). Phoresis and parasitism in. cetaceans, a review. Invest. Cetacea 14: 233-335

Baldridge, A. (1977). The barnacle Lepas pacifica and the alga Navicula grevillei on the northern elephant seals, Mirounga angustirostris. J. Mammal. 58: 428-429

Berzin, A. A., Vlasova, L. P. (1982). Fauna of the cetacea Cyamidae (Amphipoda) of the world ocean. Invest. Cetacea 13: 149-164

Bompar, J. M., Dhermain, F., Poitevin, F., Cheylan, M. (1991). Les dauphins de Méditerranée victimes d'un virus mortel. La Recherche 22: 506-508

Bonner, W. N. (1968). The fur seal of South Georgia. Scient. Rep. Br. Antarct. Surv. 56: 1-81

Bortolotto, A., Casini, L., Stanzani, L. A. (1992). Dolphins mor- 
tality along southern Italian coasts. In: Pastor, X., Simmonds, M. (eds.) Proceedings of the Mediterranean striped dolphin mortality International Workshop. Palma de Mallorca, 4-5 November 1991 Greenpeace Med.terranean Sea Project, Palma de Mallorca, p. 33-37

Brody, M. (1989). Explaining sea mammal deaths proves challenging. Am. Soc. Microbiol. News 55(11): 595-598

Cebrian, D. (1992). The striped dolphin die-off in Greece, 1990-1992. Rapp. Comm. int. Mer Médit. 33: 287

Clarke, R. (1966). The stalked barnacle Conchoderma, ectoparasitic on whales. Norsk Hvalfangsttid. 55: 153-168

Dollfus, R. Ph. (1968). Xenobalanus globicipitis Streenstrup (Cirripedia, Thoracica) récolté sur Tursiops truncatus (Montagu) à proximitê de la côte nord du Maroc. Bull. Inst. Pêch. marit. Maroc 16: 55-60

Domingo, M., Ferrer, L., Pumarola, M., Marco, A., Plana, J., Kennedy, S., McAlistey, M., Rima, B. K. (1990). Morbillivirus in dolphins. Nature 348: 21

Domingo, M., Visa, J., Pumarola, M., Marco, A. J., Ferrer, L., Rabanal, R., Kennedy, S. (1992). Pathological and immunocytochemical studies of morbillivirus infection in striped dolphins (Stenella coeruleoalba). Vet. Pathol. 29: $1-10$

Duguy, R. (1989). Les mammifères marins de la Mediterranée occidentale. Bull Soc. zool. France 114 (3): 89-96

Duignan, P. J., Geraci, J. R., Raga, J. A., Calzada, N. (1992). Pathology of morbillivirus infection in striped dolphins (Stenella coeruleoalba) from Valencia and Murcia, Spain. Can. J. vet. Res. 56: 242-248

Kasuya, T., Rice, D. W. (1970). Notes on baleen plates and on arrangement of parasitic barnacles of gray whale. Scient. Rep. Whales Res. Inst., Tokyo 22: 39-43

Margolis, L., Esch, G. W., Holmes, J. C., Kuris, A. M., Schad, G. A. (1982). The use of ecological terms in parasitology

Responsible Subject Editor: M. D. Dailey, Fort Lauderdale, Florida, USA
(Report of an ad hoc committee of the American Society of Parasitologists). J. Parasitol. 68(1): 131-133

Perrin, W. F. (1969). The barnacle, Conchoderma auritum, on a porpoise (Stenella graffmani). J Mammal. 50(1): $149-151$

Pilleri, G. (1970). Xenobalanus globicipitis Steenstrup on Delphinus delphis, Stenella styx and Tursiops truncatus of the Western Mediterranean. Invest. Cetacea 2: 247-249

Raga, J A. (in press). Parasitismus bei den Cetacea. In: Duguy, R., Robineau, D. (eds.) Handbuch der Säugetiere Europas, Vol. VI, Part I, Meeressäuger Aula-Verlag, Wiesbaden

Raga, J. A. (1988). On some morphological variations of the Syncyamus aequus Lincoln et Hurley, 1981 (Amphipoda: Cyamidae) from the Mediterranean Sea. Crustaceana $54(2): 149-152$

Raga, J. A., Carbonell, E. (1985). New data about parasites on Stenella coeruleoalba (Meyen, 1833) (Cetacea: Delphinidae in the western Mediterranean sea. Invest. Cetacea 17: $207-213$

Scarff, J. E. (1986). Occurrence of the barnacles Coronula diadema, C. reginae and Cetopirus complanatus (Cirripediaj on right whales. Sci. Rep. Whales Res. Inst., Tokyo 37: $129-153$

Stirling, I. (1971). Studies on the behavior of the South Australian fur seal, Arctocephalus forsteri (Lesson). II Adult females and pups. Aust. J. Zool. 19: 267-273

Van Bressem, M. F., Visser, I. K. G., Van de Bildt, M. W. G., Pettema, J S., Raga, J. A., Osterhaus, A. D. M. E. (1991). Confirmation of morbillivirus infection in Mediterranean striped dolphins (Stenella coeruleoalba). Vet. Rec. 129: $471-472$

Webb, J. (1991). Dolphin epidemic spreads to Greece. New Scient. 131(1785): 18

Manuscript first received: July 10,1993

Revised version accepted: November 11, 1993 